\title{
Student Interns' Core Values: A Case Study of the Mathematics Education Program
}

\author{
Weerasuk Kanauan', Maitree Inprasitha ${ }^{2}$, Narumon Changsri², Anake Sudjamnong3 \\ ${ }^{1}$ Doctoral Program in Mathematics Education, Faculty of Education, KhonKaen University, KhonKaen, Thailand \\ ${ }^{2}$ Centre of Excellence in Mathematics, CHE, Bangkok, Thailand \\ ${ }^{3}$ Mathematics and Statistics Program, Faculty of Science and Technology, SuratthaniRajabhat University, Suratthani, Thailand \\ Email: weerasuk.k@kkumail.com, inprasitha_crme@kku.ac.th,Changsri_crme@kku.ac.th, sud_anake@hotmail.com
}

How to cite this paper: Kanauan, W. Inprasitha, M., Changsri, N., \& Sudjamnong, A. (2019). Student Interns' Core Values: A Case Study of the Mathematics Education Program Creative Education, 10, 1653-1669.

https://doi.org/10.4236/ce.2019.107118

Received: May 20, 2019

Accepted: July 26, 2019

Published: July 29, 2019

Copyright (c) 2019 by author(s) and Scientific Research Publishing Inc. This work is licensed under the Creative Commons Attribution International License (CC BY 4.0).

http://creativecommons.org/licenses/by/4.0/

\section{Open Access}

\begin{abstract}
The research focuses on determining the student interns' perceptions about the 4 core values according to Inprasitha (2013). The participants were 124 student teachers in the mathematics education program, at KhonKaen University during the 2017 school year. Data were collected by questionnaires, interviews after their completion of practicum and participatory observation. Data were analyzed by descriptive statistics and content analysis. The results revealed $100 \%$ of student interns perceived each value. The four values are: 1) Building Collaboration: they valued students' working together and recognized the need to compromise opinions arising from mutual discussions while planning and reflecting together; 2) Open-Minded Attitudes: they valued listening to comments from their peers, and they valued waiting for students to understand the problem/situation by themselves and gave students the opportunity to think by themselves and explain their ideas; 3) Public Concern: they valued supporting student learning in the classroom and taking care of all students, and they could help with school activities and; 4) Emphasis on Product-Processes Approach: they valued thoroughly planning, anticipated students' ideas and patiently waited for students to solve their own problems.
\end{abstract}

\section{Keywords}

Lesson Study, Core Values, Initial Teacher Education Program, Extracurricular Activities

\section{Introduction}

Initial teacher education faces issues associated with transforming the identity of student teachers from that of student to that of teacher (Ponte \& Chapman, 2008). Preservice preparation is a time to begin developing a basic repertoire for 
reform-minded teaching and is a time to form habits and skills necessary for the ongoing study of teaching in the company of colleagues (Feiman-Nemser, 2001). Initial teacher education is primarily concerned with developing proficiency with a number of different dimensions of teacher knowledge, from teachers' knowledge of mathematical content to teachers' knowledge of pedagogy and didactics (Liljedahl et al., 2009). So, the initial teacher preparation program has closely linked and is a great impact on the quality of teachers (Inprasitha, 2013; Sowder, 2007; Office of the Education Council, 2015).

In Thailand, the general initial teacher education program operates in accordance with the standards framework announced by the Ministry of Education and the professional aspect is supervised by the Teachers Council of Thailand (Ministry of Education, 2011; The Teachers' Council of Thailand, 2013). During the last 3 decades, the initial teacher education program has undergone many changes. There are a variety of models of the program which encourage good students to enter the teacher profession. But the overall teacher productivity in the country still encounters many obstacles, both in quantity and quality. This includes teachers who are unable to teach in accordance with education in the 21 st century and the most crucial problem among every model of the program is the spirit of the teaching profession (Inprasitha, 2013; Office of the Education Council, 2017). Inprasitha (2013) proposed that every institution lacks a practical approach that will mold students into the quality of teachers required by society (Inprasitha, 2013; Office of the Education Council, 2017).

As mentioned above, the mathematics education program, faculty of education, KhonKaen University, Thailand, initiated a new model of teacher education based on Inprasitha's ideas (2013) which were driven by 4 core values. This program aims to build the spirit of the teaching profession through participating in extracurricular activities related to the core values during year 1 - year 5 . These 4 core values have been designed by weaving together the 3 steps of Lesson Study. So, student interns received training beginning in their first year through extracurricular activities, and they have been trained to be a member of a professional learning community in a school project. The research question was: how they do students perceive the 4 core values throughout engagement in activities during their 5 -year program?

\section{New Teacher Education Program}

\subsection{Mathematics Teacher Education Program According to Inprasitha's Ideas}

Thai traditional teacher education has a basic understanding that teachers have a duty to transfer knowledge from teacher to students. The initial teacher education program, therefore, provides the value that teachers need to have mathematical content, teaching material, and teaching methods to convey content to students. But education for the 21st century gives importance to teaching and learning that emphasizes thinking skills; teachers are able to focus on the students' 
thinking process (Inprasitha, 2016; Inprasitha, 2015; Inprasitha, 2007). As mentioned above, KhonKaen University, Thailand initiated a new model of teacher education in 2004. Inprasitha (2015) concludes that the features of the new teacher education program, according to Inprasitha's ideas are as follows: 1) Building a community which is the immediate link between pre-service and in-service programs; 2) Designating what kinds of practices we want them to cultivate from the beginning (Thailand uses Open Approach and Lesson Study); 3) Since we enculturate new classroom culture, the new teacher education program is what we call a "values-driven" program; and 4) A long-lasting, unresolved problem among alignment of subject matters and pedagogy has been tackled by using the PCK idea.

However, during the last 3 decades, the initial teacher education program in Thailand has undergone many changes. However, the most crucial problem among every model of the program is the spirit of the teaching profession. As mentioned, KhonKaen University, Thailand initiated a new model of teacher education based on Inprasitha (2013) which is driven by 4 core values (Inprasitha, 2013). This 5-year Mathematics Education Program aims to build teachers with the spirit of the teaching profession through participating in 4 core value activities from year 1 to year 5 . These 4 core value activities have been designed by weaving together the 3 steps of Lesson Study. In the final year, student teachers practice teaching at project schools that use the teaching practice of lesson study to incorporate an open approach consisting of a lesson study team, teaching practices in weekly cycle and school support and university support (Changsri et al., 2012). Inprasitha (2013) explained that during the last decade (2004-2013), the Faculty of Education, KhonKaen University was challenged to design a new type of teacher education program. Based on the idea of pedagogical content knowledge, they made a distinctive program by dividing the major course into three categories, that is: collegiate or advanced mathematics, school mathematics, and mathematical learning processes. Moreover, the program is intentionally planned based on the idea of educational values and educational theoretical frameworks: reflective thinking (Dewey, 1933 cited in Inprasitha, 2013) and community of practice as a learning community (Lave \& Wenger, 1991 cited in Inprasitha, 2013).

Based on the perspective of values education, four core values have been selected that are driven in mathematics teacher education program (Inprasitha, 2016; Inprasitha, 2013). The details about the four core values have been expanded as follows (Inprasitha, 2013):

1) Building Collaboration emphasizes that members of the community are aware of the identity of each member, and give value to all members because everyone is an important person. While working together, they share ideas and also listen to the arguments and suggestions of each member in the community in order to ensure success.

2) Public Concern emphasizes that members of the community are aware of the public with regard to others rather than oneself. Having good intentions, 
students will gain a public mind through various activities which will be a valuable experience that cultivates values which are based on Thai society and empower students to be able to live in a society.

3) Open-minded Attitudes emphasize that members of the community are willing to listen or consider new ideas from other members of the community even if it is a criticism or suggestions.

4) Product-Processes Approach, emphasizes students valuing their work in both the processes and results. In particular, the emphasis on the process part helps students understand each procedure of the process and history of those results.

These 4 core value activities have been designed by weaving together the 3 steps of Lesson Study. Student interns have received since their first year through a variety of social extracurricular activities according to Table 1 and Figure 1 , during which time the four core values were nurtured. The idea of a community of practice brought into the program a focus on individual participation in every activity (Inprasitha, 2007; Inprasitha, 2013).

All extracurricular activities follow the process of lesson study based on Inprasitha (2010). The process is three steps as shown in Figure 2. Step 1: Collaboratively planning, step 2: Collaboratively doing and step 3: Collaboratively reflecting. They were trained to use lesson study cycle as an approach for improving work on all activities and containing four core values that drive the mathematics teacher education program. Inprasitha (2013) put it; "The idea was practically implemented in the simplest fashion by allowing students the time to reflect upon whatever activity they had done." The central issues are on "reflection" rather than what they had done (Inprasitha, 2016; Inprasitha, 2013).

Table 1. Summary of extracurricular activities in mathematics education program.

\begin{tabular}{|c|c|}
\hline $\begin{array}{l}\text { Extracurricular Activities/ } \\
\text { Responsible Students }\end{array}$ & Activities \\
\hline Children Day/1st year & $\begin{array}{l}\text { Student teachers provide mathematical activities for children on } \\
\text { Thailand National Children's Day. }\end{array}$ \\
\hline $\begin{array}{l}\text { Math Camp/Sports Day/ } \\
\text { 2nd year and } 4 \text { th year }\end{array}$ & $\begin{array}{l}\text { Math Camp is an activity for student teachers to learn to work together. } \\
\text { They join activities as organizers at school with peers, seniors, school } \\
\text { teachers, director and lecturers. They create mathematical activity and } \\
\text { recreate activities to enhance desirable characteristics for children. } \\
\text { Sports Day is an activity that places emphasis on participation in sports } \\
\text { activities. }\end{array}$ \\
\hline Study Tour/3rd year & $\begin{array}{l}\text { Participants include more than } 300 \text { undergraduate students, graduate } \\
\text { students and lecturers. Student teachers were the organizer of this } \\
\text { activity. They learned to manage service, working together through } \\
\text { study tours both domestic and international. }\end{array}$ \\
\hline $\begin{array}{l}\text { Participating in classroom } \\
\text { activities/4th year }\end{array}$ & $\begin{array}{l}\text { Student teachers observe classes and learn the work of teachers at } \\
\text { school. }\end{array}$ \\
\hline Practicum $/ 5$ th year & $\begin{array}{l}\text { In the final year, we call them student interns. They practiced teaching } \\
\text { at project schools for } 1 \text { school year, or } 2 \text { semesters. They practice } \\
\text { teaching with lesson study incorporating open approach consisting of } \\
\text { lesson study teams in weekly cycles. }\end{array}$ \\
\hline
\end{tabular}




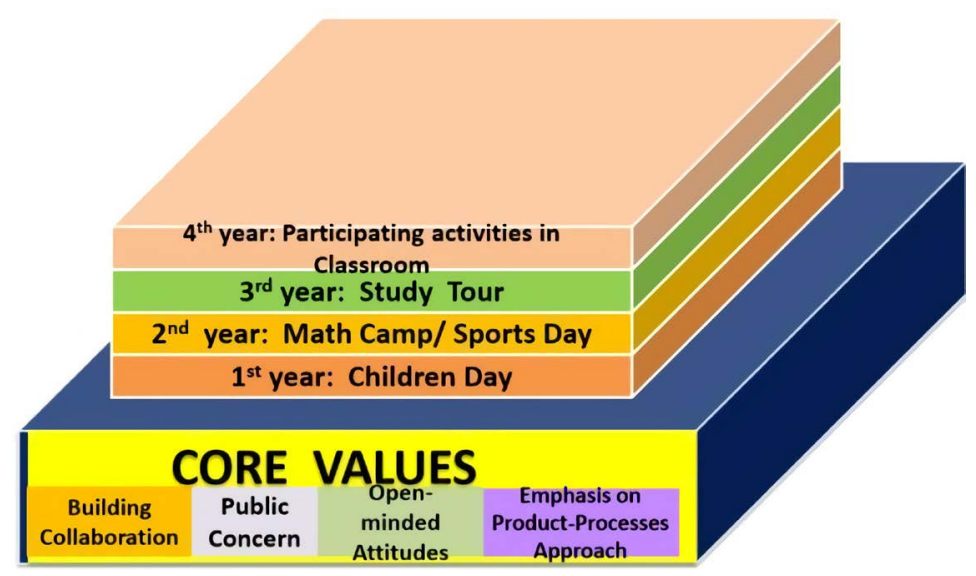

Figure 1.Core values through extra activities adapted from Inprasitha (2015).

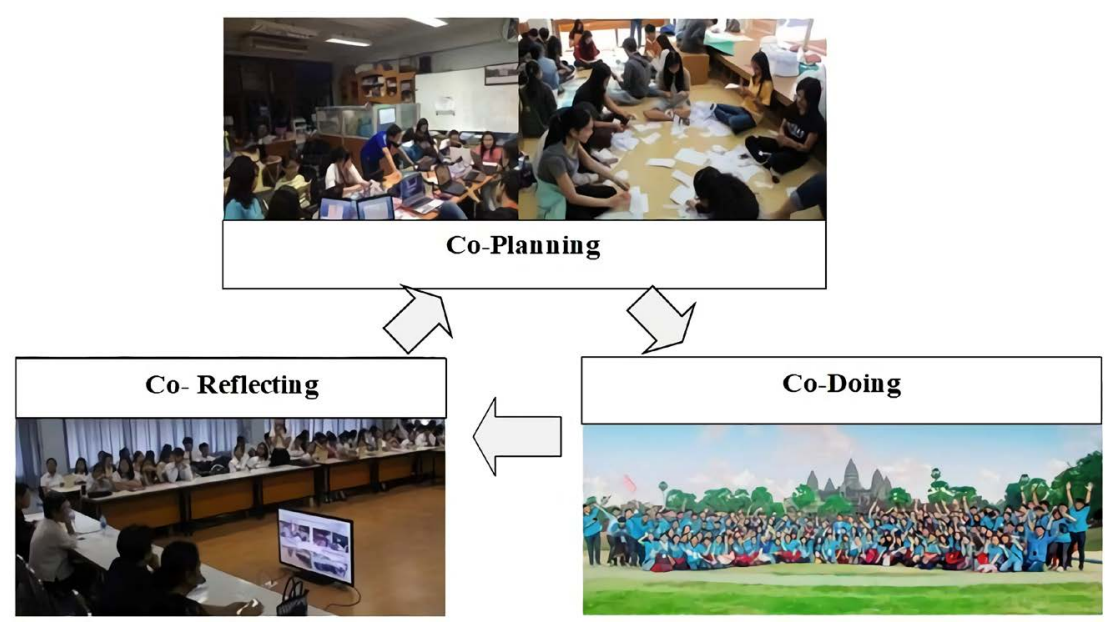

Figure 2. Lesson study process for doing each activity in teacher education programs according to Inprasitha's idea (2010).

In mathematics education, Faculty of education, KhonKaen University, student teachers have been trained to be a member of a professional learning community in a school project including in-service teachers, principals, supervisors, graduate students, and teacher educators (Inprasitha, 2015). So, the structure of the mathematics education community is comprised of a group of people with a variety of statuses, including age, year and educational level. Throughout the program, from year 1 to year 5, student teachers participate in extracurricular activities in all 3 roles including the role of participants in activities as the younger students, the role of event organizer and the role of senior. Community structure in the program found that students in the 5-year mathematics education program had the opportunity to participate in main core value activities and participated in 3 roles. In the final year of the Mathematics Education program, student interns use teaching practices with lesson study incorporating open approach at schools project of the students' mathematical higher thinking development project in northeastern of Thailand, consist of lesson study team in weekly cycle (Changsri, 2012). 


\subsection{Lesson Study}

Lesson Study originated in Japan from Japanese Language "Jugyokenkyuu". The major point of Lesson Study in every process was teachers working together (Stigler \& Hiebert, 1999; Baba, 2007). The implementation of Lesson Study included various steps by different researchers: Stigler \& Hiebert (1999) specified eight steps; Lewis (2002) specified four steps, whereas Fernandez \& Yoshida (2004) specified six steps. The number of steps of Lesson Study differed, but there was the same goal of working together based on the Lesson Study process. It might be said that the simple steps of lesson study include collaboration in planning, observing and reflecting (Inprasitha, 2007). As Shimizu \& Chino (2015) put it, in Japan, there is growing interest in using Lesson Study to foster a practical grounding for prospective teachers as part of their pre-service education courses and it plays an important role in teacher education in Japan in both pre-service education for new teachers and the in-service professional development for licensed teachers also.

In Thailand, Lesson Study was implemented originally by Associate Professor Maitree Inprasitha, Ph.D. (in Thai) in 2000. His Lesson Study prepared the context for applying innovation into four areas of implementation:1) the teacher education program, 2) the graduate study program, 3) in-service teacher training and 4) long-term teaching professional development which was tried out with the fourth year students practicing in their internship in 2002 (Inprasitha, 2015). Inprasitha (2010) researched and developed Lesson Study for Thai school culture with a unique adaptation from Japanese professional development as shown in Figure 3 and into three steps: 1) collaboratively designing research lesson, 2) Collaboratively observing the research lesson, 3) Collaboratively reflecting on teaching practice. It was a weekly activity throughout a school year and was aligned with the open approach to teaching which included four steps: 1) posing open-ended problems, 2) student's self-learning through problem solving, 3) whole class discussion and comparison, and 4) summarization through students' mathematical idea association occurring in the whole class (Inprasitha, 2010).

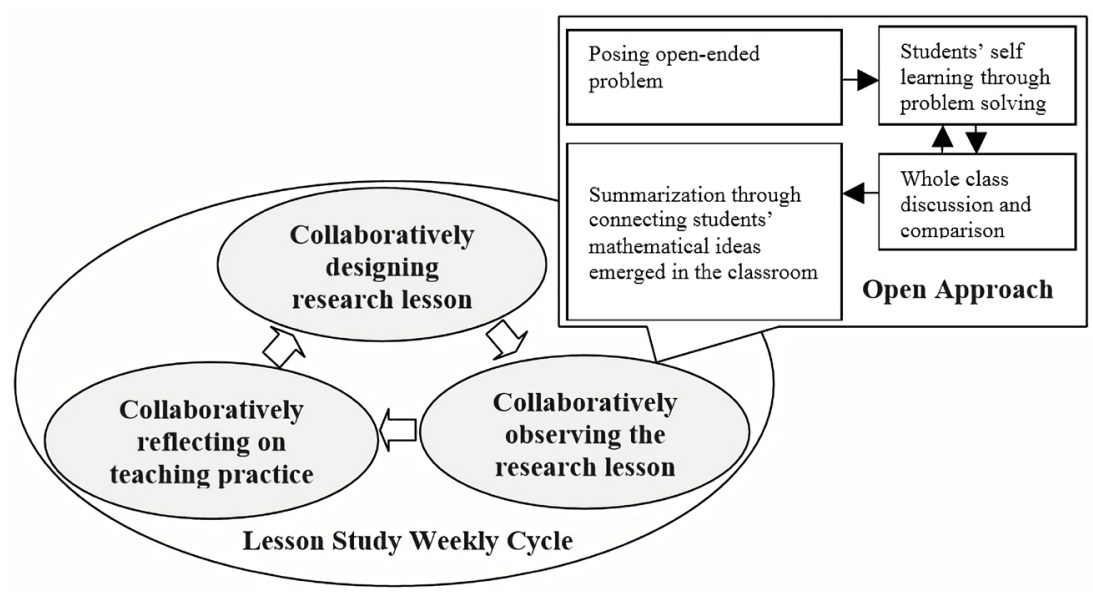

Figure 3. Model of lesson study cycle and open approach, according to Inprasitha (2010). 
For Mathematics Education, KhonKaen University, Lesson Study is a tool for developing student teachers in three key features including knowledge, skills and processes, and desirable characteristics. The mathematics education program also aims to build the spirit of the teaching profession through participating in 4 core value activities during year 1 to year 5 using Lesson Study. The student interns learn about the Lesson Study process from courses in the program such as course of school mathematics, mathematics learning process and practicum and doing extracurricular activities.

For Lesson Study of extracurricular activities, before student interns practiced at school projects, they attended activities both in the course and extracurricular activities. For extracurricular activities, they were trained to work based on lesson study cycle as an approach for improving work in all activities.

The Mathematics Education program, faculty of education, KhonKaen University, promotes core values through extracurricular activities. The participants in each activity were a variety of statuses, ages, years and level of education. Activities were designed for students to have the opportunity to take part in social activities throughout the 5 years and have the opportunity to take part in activities in 3 positions including the younger students, event organizers and seniors. For all activities, the group of student teachers who were the event organizers has conducted the 3 main steps of Lesson Study according to Inprasitha (2010) as follows:

1) Collaboratively planning: The group consists of undergraduate students, graduate students and lecturers. There is a division of responsibility in the work department, for paying attention to detailed planning and taking a long time to plan more than one cycle following these step: collaboratively planning with peers, revising the plan, collaboratively planning with the seniors, revising the plan, collaboratively planning and getting advice from lecturers and revising the plan with peers and seniors.

2) Collaboratively doing: Students have the opportunity to participate in all 3 positions, including the younger students, event organizers and seniors. All activities require cooperation in work, a common problem-solving situation, learning to accept other people's opinions and seeing the common interest rather than personal interest.

3) Collaboratively reflecting: this was divided into 3 phases, including: joining all activities after the preparatory meeting reflecting in subgroups according to each work department and reflecting together with all work departments. There were two levels of reflecting after joint activities including level 1: reflection to improve conducting activities, level 2: reflection for learning after engaging in social activity and building awareness of core values.

For Lesson Study during practicum in the last year of the program, student interns teaching practices include a weekly cycle of Lesson Study in 3 main steps according to Inprasitha (2010) as follows:

1) Collaboratively designing research lesson, Students teacher and mentor teacher create problem/situations and predict the students' ideas. They prepare learning materials and teaching equipment according to student response, as 
shown in Figure 4.

2) Collaboratively observing the research lesson: Student interns taught with the open approach which included four steps (Inprasitha, 2010): 1) posing open ended problems, 2) students' self-learning through problem solving, 3) whole class discussion and comparison, and 4) summarization through students' mathematical idea association occurring in the whole class. They observed in the classroom based on their classroom observations in the previous years, mentor teachers/student interns took their roles in observing and recording students' ideas, ways of solving problems, etc., in order to bring to the discussion to the third phase, as shown in Figure 5.

3) Collaboratively reflecting on teaching practice: At the end of the week, all teachers in the school have weekly reflections together. In this phase, the school principal conducted the meeting as moderator of this activity. Student interns act as an instructor and present the results of their teaching to mentor teachers, other observers and school principals. They discussed about students' ideas and students' responses to problems/situations and mathematical concepts and recorded the results to improve teaching, as shown in Figure 6.

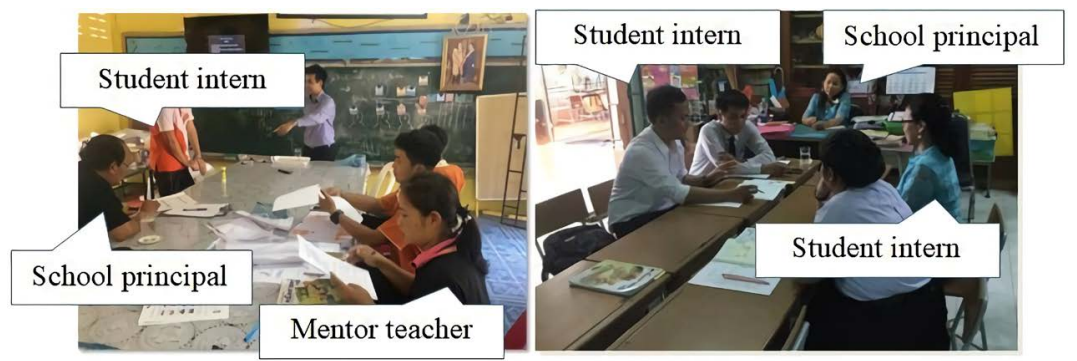

Figure 4. The incident while collaboratively designing research lesson during practicum.

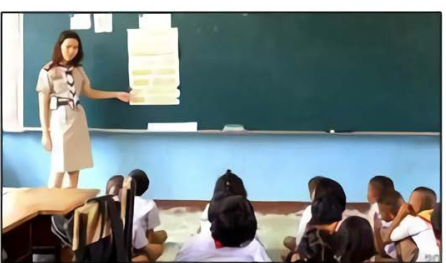

Posing open ended problems

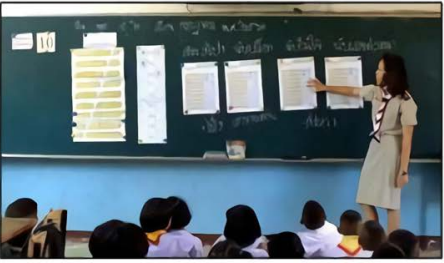

Summarization through students' mathematical idea association occurring in the whole class

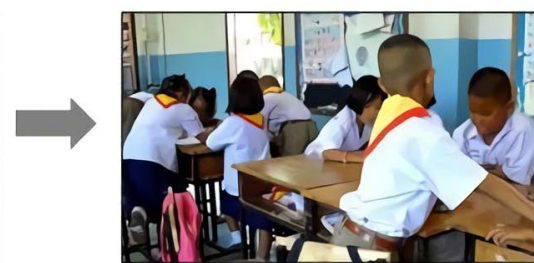

Student's self-learning through problem solving
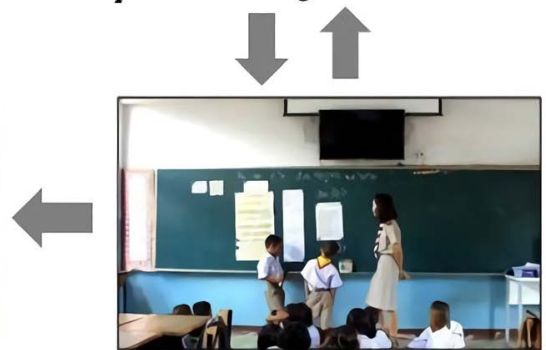

Whole class discussion and comparison

Figure 5. The incident while student intern teaches mathematics with 4 steps of the open approach, according to Inprasitha's idea (2010). 
The components of the extracurricular activities are consistent with the components of teaching practice in educational institutions, as shown in Table 2. The program has trained student interns to have core values to support teaching practice in schools that emphasis students' thinking and learning together with others in professional learning communities.

\section{Research Objectives}

To analyze student interns' perceptions about the 4 core values: a case study of the mathematics education program.

\section{Research Methodology}

\subsection{Participants}

This study was conducted in the context of the Mathematics Education Program, Faculty of education; KhonKaen University is a 5-year initial teacher education program. Participants were 124 student interns of the Mathematics Education Program, Faculty of Education, KhonKaen University. They can teach mathematics at both primary and secondary levels by choosing one throughout 1 academic year, but most the participants teach at the elementary level. All participants are between age 22 and 23, and vary in gender. The participants' studies in the 5-year mathematics education program from the academic years 2014 to 2018 .

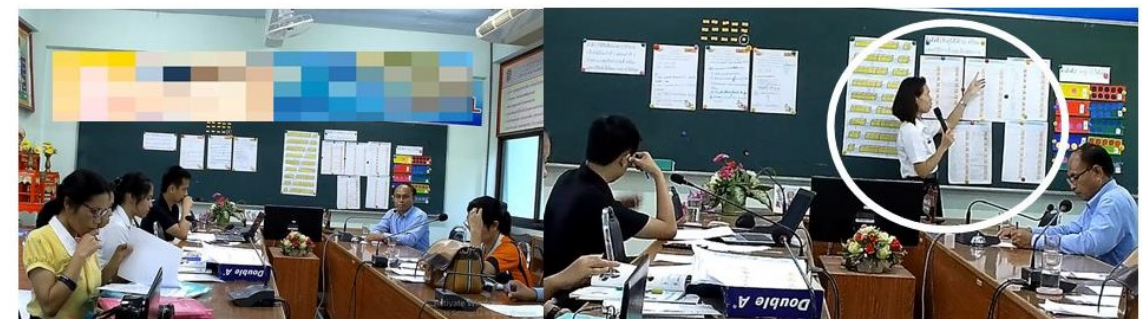

Figure 6. The incident while student intern collaboratively reflects with the school principal, mentor teacher and other teachers.

Table 2. Components of the community in extracurricular activities and practicum at school project.

\begin{tabular}{|c|c|c|}
\hline Item & Extracurricular activities & Practicum at school project \\
\hline Members & $\begin{array}{l}\text { Lecturers, bachelor degree students } \\
\text { Year } 1 \text { to Year 5, Master's degree } \\
\text { students and doctoral students }\end{array}$ & $\begin{array}{l}\text { Mentor teacher, in-service teachers, } \\
\text { principals, supervisors, graduate students, and } \\
\text { Lecturers }\end{array}$ \\
\hline Goal of practice & $\begin{array}{l}\text { To improve how activities are } \\
\text { conducted, working better together } \\
\text { and learning core values. }\end{array}$ & $\begin{array}{l}\text { To improve own teaching and student } \\
\text { thinking. }\end{array}$ \\
\hline Practice & $\begin{array}{l}\text { - Collaboratively planning } \\
\text { - Collaboratively doing } \\
\text { - Collaboratively reflecting }\end{array}$ & $\begin{array}{l}\text { - Collaboratively designing research lesson } \\
\text { - Collaboratively observing the research } \\
\text { lesson } \\
\text { - Collaboratively reflecting on teaching } \\
\text { practice } \\
\text { It was a weekly cycle. }\end{array}$ \\
\hline
\end{tabular}


They were trained since their first year through a variety of extracurricular activities such as Children's day (Y1), Sports' Day (Y2), Math Camp (Y2-Y4), Study Tour (Y3) and School Visit (Y4) during which time the four core values were nurtured. They did 4 core value activities, including 60 events ( 5 years, 4 activities and 3 times of lesson study cycles for each activity $=60$ events.) In the final year, all participants practiced teaching mathematics in project schools (Higher-Order Thinking in Mathematics Project in Northeast) for 1 academic years, or about 8 months in 2 semesters. The participants used teaching practice with lesson study incorporating open approach consisting of a lesson study team and teaching practices in weekly cycles. And then, a small number of participants as a target group were selected purposefully for in-depth study, including 12 student interns.

\subsection{Data Collection}

Data were collected in two phases. Firstly, we collected data with 124 student interns after their completion of the practicum by using a questionnaire referring to determine the student teachers' perceptions about the 4 core values according to Inprasitha (2013) and what they learned after participated in those activities, and the values/benefits of participating in extracurricular activities. Secondly, after collecting data in phase 1, we collected data with 12 student interns for in-depth study by using a semi-structured interview, including clusters of questions referring to the practical way of doing extracurricular activities according to the lesson study approach to enhance the core values following Inprasitha' ideas (2015) and their reflections about what they have learned after participating in those activities and what they perceived about values/benefits of participating in extracurricular activities for teaching practice. Methodological triangulation by using questionnaires, interviews and participatory observation were all used.

\subsection{Data Analysis}

This research aimed to focus on student teachers' perceptions about the core values, for qualitative data from the questionnaire, we used content analysis method. For the data from interviewing, we transcribed them and then analyzed the data by content analysis of student interns' perceptions about the 4 core values following Inprasitha's ideas (2015): building collaboration, open-minded attitudes, public concern and emphasis on product-processes approach.

\section{Research Results}

The research results focus on student interns' perceived core values after they engaged in all activities of the Mathematics Education Program, Faculty of Education, KhonKaen University. Student interns have perceptions about the core values as follows.

As shown in Table 3, it is revealed that $100 \%$ of student teachers perceived each value. Everyone recognized that they were encouraged to build values from engaging in all activities in the program. The four values are: 
1) Building collaboration: Every activity was organized according to Lesson Study cycle, encouraging student teachers to work together through planning, participation and reflection. There was division of responsibilities in the department and the participation of diverse groups helps student teachers to learn to work with others. The following findings are some examples of opinions as expressed by the student interns:

"The program focuses on working with others, whether the person who you work with is known or unknown because I always know to accept the opinions of others and to work with others who have levell age differences and learn to work with peers in a same year who have a variety of attitudes."

(Student intern number 99, February 21, 2018)

During practicum, they used teaching practices with emphasis on student collaboration. While planning together, student teachers valued the opinions generated by the discussion. While reflecting together, student teachers valued the reflection on students' ideas for improving teaching.

2) Open-minded attitudes: They valued listening to comments from their peers and learning to accept others whom they collaboratively plan and reflect. With student interns valued the acceptance of others' opinions and valuing the acceptance of individual differences, with an open mind. The following findings are some examples of opinions as expressed by the student interns:

"The experience gained from the program helped me to work with others and systematically plan. Reflections after working help me learn about problems in the workplace and predicting of various problems. So I accepted other people's ideas and was a person who is ready to learn and participate in the face of events/situations on their own and rather than closing myself off from things that are useful for learning and self-improvement."

(Student intern number 26, February 21, 2018)

During practicum they valued patiently waiting for students to understand the problem/situation by themselves, providing opportunities for students to solve problems on their own and giving students the opportunity to show reasons. From participation observation, during a phase of posing the problem/situation, student interns valued create an atmosphere for students to participate in answering questions and allowing all students to express their opinions even if they are is right or wrong. They focused on participation according to student experience and

Table 3. Student interns' perceptions on perceiving that owners have been promoted core values.

\begin{tabular}{ccc}
\hline \multirow{2}{*}{ Core values } & \multicolumn{2}{c}{ Perceiving that own have been promoted core values } \\
\cline { 2 - 3 } & Frequency $(\mathrm{N}=124)$ & Percentage (\%) \\
\hline Building collaboration & 124 & 100 \\
Open-minded attitudes & 124 & 100 \\
Public concern & 124 & 100 \\
Emphasis on product-processes approach & 124 & 100 \\
\hline
\end{tabular}


gave the opportunity for students to express their opinions on open-ended problems situations, listening to every student's answer. From Item46 to Item56, a student intern presented a picture as the material on the board, and response asked, "How many blocks are there?" One student replied, "There are ten" which was the corresponding to the number of blocks in the picture. The student intern used repetition of students' responses without judging whether they are right or wrong, then asking the students that "What about the other students?" The following findings were some examples as expressed in the classroom from Item 46 to Item56:

Item46 Student intern: Let's guess what activities we will have.

(Student intern sticks picture on the board)

Item47 students: I saw the blocks.

Item48 Student intern: Saw the blocks.

Item 49 student 1: There were ten blocks.

Item50 Student intern: Ten blocks, what do other people see?

Item51 student 2: Square block.

Item52 Student intern: Next, what are the next predictions? How much is this?

Item53 students: Ten/Nine.

Item54 Student intern: Why is it nine?

Item55 student 3: It intersects.

Item56 Student intern: It contrasts with another one. What about other students?

3) Public concern: Every activity must be done together and there is mutual help between members so those who were promoting them valued seeing the common interest rather than personal interest. The following findings are some examples of opinions as expressed by the student interns.

"Activities in the program must be done together, plan together and reflect together. Everyone must sacrifice personal time to help friends to organize various activities. We have to help each other. During the younger generation being an event organizer, we must join in activities and encouragement them"

(Student intern number 91, February 21, 2018)

Valuing public concern promotes emphasis on facilitating student thinking in the classroom, valuing caring for every student, and valuing assistance with the activities of the school. From participation observing, student interns valued the role of facilitating the management of students' ideas. The student interns prepared the material to expand the student ideas. Student interns facilitated student thinking and took care of all students by attaching learning materials and writing on the board according to the words that students described as their reason/ideas as shown in Figure 7.

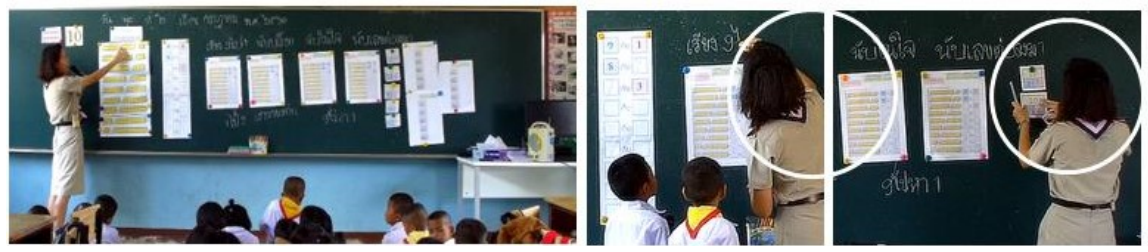

Figure 7. Showing the incident while student intern act as a facilitator for student learning. 
4) Emphasis on product-processes approach: Every activity provided value to detailed planning and anticipated what would happen with emphasis to patiently wait to hear the opinions of others and reflections for improving work and sending information to those responsible for activities the following year. The following findings are some examples of opinions as expressed by the student interns.

"Activity in the program that is useful for teaching practice is the study tour activity which students in year 3 are organizers of because organizing this activity requires systematic planning and problem solving, including having to be careful and working step by step according to the process to prevent errors from occurring."

(Student intern number 64, February 21, 2018)

Valuing on emphasis on product-processes approach prompts them the importance of systematic work planning, with emphasis on anticipating the students' ideas in order to prepare teaching. They were patiently waited for students to solve problems by themselves and did not disturb them.

As mentioned, student teachers were trained since their first year through a variety of extracurricular activities and they were also trained to be a member of professional learning community in a school project. The result of this research at phase 2 focuses on student interns' perceptions about the 4 core values that they perceived during practicum as follow Tables 4-6.

Table 4. Summarizes student interns' perceptions of core values while collaboratively designing the research lesson during practicum.

\begin{tabular}{|c|c|c|c|c|}
\hline \multirow[b]{2}{*}{ Lesson Study } & \multicolumn{4}{|c|}{ Core values } \\
\hline & $\begin{array}{l}\text { Building } \\
\text { Collaboration }\end{array}$ & $\begin{array}{l}\text { Open-minded } \\
\text { attitudes }\end{array}$ & Public concern & $\begin{array}{c}\text { Emphasis on product-processes } \\
\text { approach }\end{array}$ \\
\hline $\begin{array}{l}\text { Collaboratively } \\
\text { designing } \\
\text { research lesson }\end{array}$ & $\begin{array}{l}\text { - Express opinions in a creative way } \\
\text { that is useful for improving } \\
\text { teaching. } \\
\text { - Valuing compromise opinions } \\
\text { arising from mutual discussions } \\
\text { while planning together. }\end{array}$ & $\begin{array}{l}\text { - Listen and accept the } \\
\text { opinions of others. } \\
\text { - Listen to suggestions to } \\
\text { improve the teaching. }\end{array}$ & $\begin{array}{l}\text { - Act as facilitator during } \\
\text { collaborative planning. } \\
\text { - Produce the learning } \\
\text { materials for students } \\
\text { intentionally. }\end{array}$ & $\begin{array}{l}\text { - Valuing planning the lesson } \\
\text { plans thoroughly at every step. } \\
\text { - Valuing anticipating students' } \\
\text { ideas to prepare for effective } \\
\text { teaching. }\end{array}$ \\
\hline
\end{tabular}

Table 5. Summarizes student interns' perceptions of core values during collaboratively observing the research lesson during practicum.

\begin{tabular}{|c|c|c|c|c|}
\hline \multirow[b]{2}{*}{ Lesson Study } & \multicolumn{4}{|c|}{ Core values } \\
\hline & $\begin{array}{c}\text { Building } \\
\text { Collaboration }\end{array}$ & $\begin{array}{l}\text { Open-minded } \\
\text { attitudes }\end{array}$ & Public concern & $\begin{array}{c}\text { Emphasis on } \\
\text { product-processes approach }\end{array}$ \\
\hline $\begin{array}{l}\text { Collaboratively } \\
\text { observing the } \\
\text { research lesson }\end{array}$ & $\begin{array}{l}\text { - Emphasis on student } \\
\text { collaboration. } \\
\text { - Give students the } \\
\text { opportunity to freely } \\
\text { present their own ideas. }\end{array}$ & $\begin{array}{l}\text { - Emphasis on students } \\
\text { understanding their problem } \\
\text { by themselves. } \\
\text { - Valuing patiently waiting for } \\
\text { students to solve the problem } \\
\text { by themselves. } \\
\text { - Being a listener intentionally } \\
\text { - Rejoice in student success. }\end{array}$ & $\begin{array}{l}\text { - Emphasis on facilitating } \\
\text { students solving the problem. } \\
\text { - Taking care of all students. }\end{array}$ & $\begin{array}{l}\text { - Emphasis on providing learning } \\
\text { materials to help students reach the } \\
\text { problem/situation. } \\
\text { - Emphasis on detailed observations } \\
\text { according to the planned lesson } \\
\text { plan. } \\
\text { - Patiently waiting for a student to } \\
\text { solves the problem. }\end{array}$ \\
\hline
\end{tabular}


Table 6. Summarizes student interns' perceptions of core values while collaboratively reflecting on teaching practice during practicum.

\begin{tabular}{|c|c|c|c|c|}
\hline \multirow[b]{2}{*}{ Lesson Study } & \multicolumn{4}{|c|}{ Core values } \\
\hline & $\begin{array}{c}\text { Building } \\
\text { Collaboration }\end{array}$ & $\begin{array}{l}\text { Open-minded } \\
\text { Attitudes }\end{array}$ & Public concern & Emphasis on product-processes approach \\
\hline $\begin{array}{l}\text { Collaboratively } \\
\text { reflecting on } \\
\text { teaching practice }\end{array}$ & $\begin{array}{l}\text { - Reflecting on the issues } \\
\text { that arise in the } \\
\text { classroom for improving } \\
\text { teaching and developing } \\
\text { students' thinking. }\end{array}$ & $\begin{array}{l}\text { Listening and accepting } \\
\text { suggestions to improve } \\
\text { teaching practices. } \\
\text { - Improve operations } \\
\text { according to suggestions. }\end{array}$ & $\begin{array}{l}\text { - Acting as facilitator } \\
\text { during collaborative } \\
\text { reflection. }\end{array}$ & $\begin{array}{l}\text { - Reflect on the results according to the set point. } \\
\text { - Emphasis on reflecting on the results of the } \\
\text { students' ideas in detail. } \\
\text { - Emphasis on listening to suggestions from } \\
\text { others. }\end{array}$ \\
\hline
\end{tabular}

\section{Conclusion}

The Mathematics Teacher Education Program (5-year course), Faculty of Education, KhonKaen University has implemented a value-driven teacher education program according to Inprasitha $(2015,2013,2010)$, It was built upon major core concepts: problem solving as a driving force for mathematical thinking, teachers learning together, and reflection using two innovations; open approach as a teaching method and lesson study as a way to improve teaching (Inprasitha, 2015). There are integrated lesson study and the open approach for activities throughout the program, both in courses and extra-curricular activities. This program aims to build the spirit of the teaching profession through participating in extracurricular activities as core value activities during year 1 - year 5 . These corevalue activities have been designed weaving together the 3 steps of lesson study.

Student interns are aware of the value of cultivating their values through participation in the teacher production programas organizers and participants. Progressing from year 1 to year 5 is a great way to learn the core values through practices consistent with the concept of learning by the sociocultural theories (Lerman, 2013) and the situative perspective that describes the meaning of learning as a change of participation in social activities (Lave \& Wenger, 1991). Learning takes place in the real world of "practice" within the community of practice (Wenger, 1998). As a result, student teachers have the opportunity to absorb the values they need to cultivate and student teachers' values are one of the criteria which affect their performance in their teaching practices (Bishop, Seah, \& Chin, 2003; Inprasitha, 2013) and indicate good quality learning and teaching (Lovat, 2005; Brady, 2011).

Student interns of Mathematics Education Program, Faculty of Education KhonKaen University have the following core values: 1) Building collaboration: Every activity was organized according to lesson study cycle, so student teachers recognized working together through planning, participation and reflection. Participation in the course and extracurricular activities helps student interns learn to work with others and follow teaching practices with an emphasis on student' collaboration. While planning together, student teachers value the compromise of opinions generated by the discussion. While reflecting together, student teachers value the reflection on students' ideas for improving teaching. 2) 
Open-minded attitudes: Student interns value the acceptance of others' opinions and valuing the acceptance of individual differences, being open minded in accepting new ideas, and valuing to patiently waiting for students to understand the problem/situation by themselves while providing opportunities for students to solve problems on their own and to show their reasons. 3) Public concern: Every activity in the program and school must include spent time together with mutual help between members so everyone values see the common interest rather than personal interest. This value promotes an emphasis on facilitating student thinking in the classroom, valuing caring for every student, and valuing assisting in the activities of the school. 4) Emphasis on product-processes approach: Every activity provides value to detailed planning and anticipating what will happen with an emphasis on patiently waiting to hear the opinions of others and reflections for improving work and sending information to those responsible for activities in the following year. This value prompts the importance of systematic work planning, emphasis on anticipating students' ideas for preparing teaching, and patiently waiting for students to solve problems by themselves and not disturb them.

Building community and participation in social practice in the courses and extracurricular activities with lesson study cycles according to Inprasitha (2013) provides a sound structure for professional learning and helps student teachers perceive and develop their core values. Research results support that one important thing for initial teacher education program is cultivating core values and undertakings can occur from doing and reflecting on their practice with others. Promotion of core values is a long-term process and is caused by accumulation through continuous participation in social activities. Finally, the essence of the activity should reflect the core values also.

\section{Acknowledgements}

This research partially supported by The Centre of Excellence in Mathematics, the Commission on Higher Education (CEM), Thailand.

\section{Conflicts of Interest}

The authors declare no conflicts of interest regarding the publication of this paper.

\section{References}

Baba, T. (2007). Japanese Education and Lesson Study: An Overview. In M. Isoda, M. Stephens, Y. Ohara, \& T. Miyakawa (Eds.), Japanese Lesson Study in Mathematics: Its Impact, Diversity and Potential for Educational Improvement (p. 1). Singapore: World Scientific Publishing.

Brady, L. (2011). Teacher Values and Relationship: Factors in Values Education. Australian Journal of Teacher Education, 36, 56-66. https://doi.org/10.14221/ajte.2011v36n2.5

Bishop, A. J., Seah, W. T., \& Chin, C. (2003). Values in Mathematics Teaching-The Hidden Persuaders? In A. J. Bishop et al. (Eds.), Second International Handbook of Mathematics Education (pp. 717-765). Dordrecht: Kluwer Academic Publishers. 
https://doi.org/10.1007/978-94-010-0273-8_24

Changsri, N. (2012). Teacher's Perceived Beliefs about Teaching Practices in Teacher Professional Development Based on Lesson Study and Open Approach Context. Doctor of Philosophy Thesis in Mathematics Education, Khon Kaen: Graduate School, Khon Kaen University.

Changsri, N., Inprasitha, M., Pattanajak, A., \& Changtong, K. (2012). A Study of Teachers' Perceived Beliefs Regarding Teaching Practice. Psychology, 3, 346-351. https://doi.org/10.4236/psych.2012.34049

Feiman-Nemser, S. (2001). From Preparation to Practice: Designing a Continuum to Strengthen and Sustain Teaching. Teachers College Record, 103, 1013-1055. https://doi.org/10.1111/0161-4681.00141

Fernandez, C., \& Yoshida, M. (2004). Lesson Study: A Japanese Approach to Improving Mathematics Teaching and Learning. Mahwah, NJ: Lawrence Erlbaum Associates, Publishers.

Inprasitha, M. (2016). Research and Development of Modern Mathematics Instruction. KKU Research, 2, 2-9.

Inprasitha, M. (2015). New Model of Teacher Education Program in Mathematics Education: Thailand Experience. In Proceedings of 7th ICMI East Asia Regional Conference on Mathematics Education (pp. 97-100). Philippines: Philippine Council of Mathematics Teacher Educators (MATHTED) Inc.

Inprasitha, M. (2013) Innovations and Exemplary Practices in Teacher Education Program in Thailand. In M. Inprasitha (Ed.), Proceedings of the 6th East Asian Regional Conference on Mathematics Education 2013 (pp. 32-43). Phuket: Center for Research in Mathematics Education (CRME), KhonKaen University.

Inprasitha, M. (2010). One Feature of Adaptive Lesson Study in Thailand-Designing Learning Unit. In Proceeding of the 45th Korean National Meeting of Mathematics Education (pp. 193-206). Korea: Korean Society of Mathematics Education.

Inprasitha, M. (2007). Lesson Study in Thailand. In M. Isoda, M. Stephens, Y. Ohara, \& T. Miyakawa (Eds.), Japanese Lesson Study in Mathematics: Its Impact, Diversity and Potential for Educational Improvement (pp. 188-193). Singapore: World Scientific Publishing.

Lave, J., \& Wenger, E. (1991). Situated Learning: Legitimate Peripheral Participation. Cambridge: Cambridge University Press. https://doi.org/10.1017/CBO9780511815355

Lerman, S. (2013). Theories in Practices: Mathematics Teaching and Mathematics Teachers Education. ZDM: The International Journal of Mathematics Education, 45, 623-631. https://doi.org/10.1007/s11858-013-0510-x

Lewis, C. (2002). Lesson Study: A Handbook of Teacher-Led Instructional Improvement. Philadelphia, PA: Research for Better Schools.

Liljedahl, P. et al. (2009). Components of Mathematics Teacher Training. In D. L. Ball, \& R. Even (Eds.), The Professional Education and Development of Teachers of Mathematics (pp. 25-31). New York: Springer.

Lovat, T. J. (2005). Values Education and Teachers' Work: A Quality Teaching Perspective. National Values Education Forum, Australian Government Department of Education Science and Training.

http://www.curriculum.edu.au/verve/_resources/Values_Conf_020505_forum_address _Lovat.pdf

Ministry of Education (2011). Bachelor's Degree in Education (5-Year Curriculum). (In Thai) http://www.mua.go.th 
Office of the Education Council (2017). System and Model of Teacher Production and Research System of Teacher Production Institutions That Are Suitable for Thai Society and Internationalization. Bangkok: Graphic Sweet Pepper.

Office of the Education Council (2015). Status of Teacher Production and Development in Thailand. Bangkok: Graphic Sweet Pepper.

Ponte, J., \& Chapman, O. (2008). Pre-Service Mathematics Teachers' Knowledge and Development. In L. D. English (Ed.), Handbook of International Research in Mathematics Education (2nd ed., Vol. 1, pp. 223-261). New York: Routledge.

Shimizu, S., \& Chino, K. (2015). History of Lesson Study to Develop Good Practices in Japan. In M. Inprasitha et al. (Eds.), Lesson Study Challenges in Mathematics Education (pp. 123-140). Singapore: World Scientific Publishing.

Sowder, J. T. (2007). The Mathematics Education and Development of Teachers. In F. K. Lester (Ed.), Second Handbook of Research on Mathematics Teaching and Learning (pp. 157-223). Charlotte, NC: Information Age Publishing.

Stigler, J. W., \& Hiebert, J. (1999). The Teaching Gap: Best Ideas from the Worlds Teachers for Improving Education in the Classroom. New York: Free Press.

The Teachers' Council of Thailand (2013). Teacher Professional Standards. (In Thai) http://www.ksp.or.th

Wenger, E. (1998). Communities of Practice: Learning, Meaning, and Identity. Cambridge: Cambridge University Press. https://doi.org/10.1017/CBO9780511803932 